\title{
INS Factory Raids as Nondetentive Seizures
}

\author{
David K. Chan
}

The Immigration and Naturalization Service (INS) conducts workplace raids throughout the country ${ }^{1}$ to locate undocumented immigrants. ${ }^{2}$ Typically, the INS obtains information that a particular business may be employing undocumented workers and places the workplace under visual surveillance. If some workers appear to fit a profile of undocumented immigrants, the INS proceeds with the raids, even though it has no knowledge of the presence of any specific undocumented workers. ${ }^{3}$

1. See INS, U.S. Dep'r OF Justice, Statistical Yearbook 192 (1983) (table listing 35 cities across country where INS conducts raids). Workplace raids are also known as business surveys or factory sweeps. The general authority of the INS to question individuals is derived from the Immigration and Nationality Act, which grants agents "power without warrant-(1) to interrogate any alien or person believed to be an alien as to his right to be or to remain in the United States ...." Immigration and Nationality Act, $\S 287,8$ U.S.C. § 1357(a) (1982).

2. This Note will use the term "undocumented immigrant" in place of the pejorative term "illegal alien." Undocumented immigrants are persons who have entered the country without inspection or with false documents, who have overstayed their visas, who are working without authorization, or who are otherwise in violation of immigration laws. See ILGWU v. Sureck, 681 F.2d 624, 626 n.1 (9th Cir. 1982), rev'd sub nom. INS v. Delgado, 466 U.S. 210 (1984).

Labeling individuals as "illegal," before there has been any judicial or administrative determination, fails to recognize that some workers who are undocumented may nevertheless be lawfully in the country, or will be granted discretionary administrative relief. See Harwood, Arrests Without Warrant: The Legal and Organizational Environment of Immigration Law Enforcement, 17 U.C.D. L. REv. 505, 509-10 (1984) (describing eligibility for suspension of deportation). The term "illegal" is also rejected because it ignores the reality of present immigration law. Lax border enforcement coupled with the encouragement and facilitation of entry by some employers suggest that, even though undocumented entry may be in technical violation of law, it has at times been welcomed by many segments of American society with tacit governmental approval. See The Immigration Mess (Both of Them), N.Y. Times, Oct. 22, 1985, at A38, col. 1 (editorial) ("II]t is nominally illegal for undocumented aliens to come to this country-but as long as employers have wanted their labor, no one has gotten heavy about enforcing the law."); Illegal Workers as Domestics: Uneasy Alliance, N.Y. Times, Oct. 30, 1985, at C1, col. 3 (families need undocumented immigrants as housekeepers and INS does not attempt to apprehend them).

3. See Sureck, 681 F.2d at 626 . For example, INS agents may confirm the information merely by observing that Hispanic workers enter the suspected workplaces. See id. at 627 n.5. The INS gains 
The raids begin when a group of 15 to 25 INS agents enter a workplace without advance warning, surround the workers, and guard all exits. " The raids often begin with "workers' cries of 'la migra' . . . followed by attempts by some workers to hide or run . . .." Agents move systematically through the workforce, displaying badges and directing pointed questions at selected workers. Those workers believed to be undocumented are handcuffed and taken away. ${ }^{6}$ The raids cause "confusion and pandemonium" and generate considerable anxiety among the employees. One worker has testified that she was afraid "[b]ecause if I leave and they think I don't have no papers and they shoot me or something."

In INS v. Delgado, the Supreme Gourt declared that workplace raids involve no Fourth Amendment seizure because questioned workers were free to walk away from the questioning. ${ }^{9}$ For the first time, a majority of

entry into the premises by obtaining either a search warrant or the consent of the establishment's owner. The consent of the owner is secured for approximately $90 \%$ of raided workplaces. See id. at 626. Thus, the INS conceivably can lawfully enter most workplaces with no specific information whatsoever.

Warrants used to authorize raids may be challenged as violative of the Fourth Amendment. Compare International Molders' \& Allied Workers' Local Union No. 164 v. Nelson, No. C-82-1896, slip op. at 6-20 (N.D. Cal. Oct. 28, 1985) (enjoining preliminary raids based on warrants that do not identify specific individuals), denying request for stay of preliminary injunction, No. 85-2745, slip op. (9th Cir. Dec. 2, 1985) with Blackie's House of Beef v. Castillo, 659 F.2d 1211, 1226-27 (D.C. Cir. 1981) (warrants for raids need not identify specific individuals), cert. denied, 455 U.S. 940 (1982). It is important to note that, if Congress authorizes sanctions for employers who hire undocumented immigrants, see S. 1200, 99th Cong., 1st Sess. (1985), employers are unlikely to consent to raids. As a result, challenges to raids may become focused on the sufficiency of warrants.

4. See Sureck, 681 F.2d at 631-32; Delgado, 466 U.S. at 229-30 (Brennan, J., concurring in part and dissenting in part).

5. Sureck, 681 F.2d at 627.

6. See Delgado, 466 U.S. at 230 (Brennan, J., concurring in part and dissenting in part).

7. Id. at 237 n.7 (Brennan, J., concurring in part and dissenting in part) (quoting UNrreD States Commission on Civil Rights, The Tarnished Golden DoOR: Civil Rights Issues in ImmigRATION 90-91 (1980)). See also INS v. Lopez-Mendoza, 104 S. Ct. 3479, 3487 (1984) (raids are chaotic).

8. Delgado, 466 U.S. at 237 (Brennan, J., concurring in part and dissenting in part). The raids have stirred forceful protests by community groups, civil rights organizations, and public officials. Described as "commando-like," Target: Illegal Aliens, NEwsweEk, May 10, 1982, at 45, "terroristic," Cranston Demands Immediate End to INS Raids, L.A. Times, Apr. 30, 1982, § I, at 3, col. 2 (quoting Sen. Cranston), and "paramilitary," id. at 23 (quoting Rev. Allan F. Deck of the Hispanic Ministry Diocese of Orange County), they have been criticized as being designed "to cause the maximum amount of disruption to employers, workers and communities," id. at 3 (quoting Sen. Cranston).

9. The Court did not address the sufficiency of the warrants used to support two of the raids. 466 U.S. 210 (1984). The Court encountered workplace raids in only one other case. In INS v. LopezMendoza, 104 S. Ct. 3479 (1984), the Court held that the exclusionary rule does not apply to deportation proceedings. Although the respondent had been apprehended during a workplace raid, the Court did not discuss the constitutionality of the raid.

Without the exclusionary rule to deter the apprehension of undocumented immigrants through constitutionally dubious tactics, it becomes even more important that the Court provide clear standards that repudiate unconstitutional practices. The establishment of clear judicial standards would help the INS to develop similarly clear administrative guidelines. INS agents seeking to abide by constitutional constraints thus would more easily be able to modify their conduct accordingly. Consequently, INS agents who may otherwise engage in unconstitutional tactics because of the abolition of the exclusionary rule may still be restrained by internal controls. See id. at 3487-88 (INS internal regulations 
the Court explicitly endorsed the view that no Fourth Amendment interest is at stake as long as an individual's freedom of movement is not restricted, that is, when the individual is not detained.

This Note criticizes the restrictive definition of "seizure" that the Court used in Delgado, and argues that a citizen or documented immigrant ${ }^{10}$ subjected to citizenship questioning ${ }^{11}$ during a workplace raid is "seized" within the meaning of the Fourth Amendment. ${ }^{12}$ The Note then proposes that the INS be governed by constitutional restrictions similar to those developed by courts to govern the police: The INS should be required to base citizenship questioning on an individualized reasonable suspicion of undocumented immigration. ${ }^{13}$ Furthermore, this reasonable suspicion may not be based on race, because doing so creates added intrusion under the

deter Fourth Amendment violations).

10. This Note assumes that documented immigrants and citizens are equally protected by the Fourth Amendment, though the Supreme Court has not yet so ruled. At one point, although the majority opinion did not reach the issue, four members of the Court expressed the view that documented immigrants are covered directly by the Fourth Amendment. See Abel v. United States, 362 U.S. 217, 248, 250 (1960) (Brennan, J., dissenting); id. at 246-47 (Douglas, J., dissenting); see also Sureck, 681 F.2d at 639; United States v. Barbera, 514 F.2d 294, 296 n.3 (2d Cir. 1975); Au Yi Lau v. INS, 445 F.2d 217, $222-23$ (D.C. Cir.), cert. denied, 404 U.S. 864 (1971). The interpretation that "the people" in the Fourth Amendment includes all individuals is consistent with the Court's holding that "person" in the Fifth and Fourteenth Amendments includes noncitizens. See, e.g., Yick Wo v. Hopkins, 118 U.S. 356, 368-69 (1886) (documented immigrants entitled to equal protection).

As the Court has often recognized, the Fourth Amendment secures an indispensable liberty. See Almeida-Sanchez v. United States, 413 U.S. 266, 274 (1973). The protection of privacy and personal security is vital to the preservation of individual dignity regardless of an individual's immigration status. See Developments in the Law-Immigration Policy and the Rights of Aliens, 96 HARv. L. REv. 1286, 1335-36, 1406 (1983) (arguing that Court's willingness to extend constitutional guarantees to documented immigrants responds to "humanitarian sentiments"); see also UNIVERSAL DECLAration of Human Rights (1948) in Human Rights: International Documents 10 (J. Joyce ed. 1978) (U.S. agreed to provide immigrants with same entitlements as citizens).

Even if documented immigrants do not enjoy direct Fourth Amendment protection, they nevertheless receive indirect protection because of the danger that citizens may be mistaken for documented immigrants, for it is clear that the rights of citizens cannot be reduced as a consequence of any lesser entitlement enjoyed by documented immigrants. See United States v. Brignoni-Ponce, 422 U.S. 873, 884 (1975) (power of Congress to regulate documented immigrants "cannot diminish the Fourth Amendment rights of citizens who may be mistaken for aliens").

Undocumented immigrants, too, may enjoy some Fourth Amendment rights. See United States v. Barbera, 514 F.2d 294, 296 n.3 (2d Cir. 1975) (Fourth Amendment protects all individuals); Babula v. INS, 665 F.2d 293, 299 n.2 (3d Cir. 1981) (Adams, J., concurring) (undocumented immigrants entitled to some protection since Fourth Amendment "speaks of 'the right of the people' and not the rights of 'citizens"').

11. Citizenship questioning includes inquiries regarding citizenship status, proper documentation, lawfulness of entry, place of birth, and related questions.

12. Although this Note focuses on workplace raids, its reasoning would also limit similar INS practices, such as stopping individuals on the street or entering residences for citizenship questioning. See, e.g., LaDuke v. Nelson, 762 F.2d 1318, 1327-28 (9th Cir. 1985) (entry into residences); Cheung Tin Wong v. INS, 468 F.2d 1123, 1124 (D.C. Cir. 1972) (street encounter); Illinois Migrant Council v. Pilliod, 398 F. Supp. 882, 887-90 (N.D. Ill. 1975) (street encounters and entry into residences), affd, 540 F.2d 1062 (7th Cir. 1976), modified as to remedy, 548 F.2d 715 (7th Cir. 1977) (en banc).

13. Like the police, the INS is a law enforcement agency; it is authorized by statute to enforce immigration laws and is empowered to conduct investigations, searches, and seizures and to make arrests. See Immigration and Nationality Act, § 287, 8 U.S.C. § 1357 (1982). 
Fourth Amendment and also violates the equal protection guarantees of the Fifth Amendment.

\section{I. "Seizures" Without Restrictions on Movement}

The Court's finding in Delgado that INS questioning of workers during raids is not a Fourth Amendment seizure rested on a recentlyformulated test: an individual has been seized only when a reasonable person under the same circumstances would not have felt free to walk away. ${ }^{14}$ The Court's test, however, incorrectly equates the general liberty interests protected by the Fourth Amendment with the specific right of freedom of movement. Even though some stops for questioning-such as citizenship questioning during workplace raids-are said to impose no restrictions on movement, they intrude so deeply on general liberty interests that they should be regarded as "nondetentive seizures" under the Fourth Amendment. ${ }^{15}$

\section{A. "Seizures" Under the Fourth Amendment}

The Court has interpreted the Fourth Amendment "right of the people to be secure in their persons, houses, papers, and effects, against unreasonable searches and seizures"16 to be the right of individuals to personal security and privacy ${ }^{17}$ free of arbitrary ${ }^{18}$ and abusive ${ }^{18}$ governmental in-

14. See Delgado, 466 U.S. at 215. Even under the Court's formula for a seizure, its view of the facts left ample room for disagreement. The decision turned on the Court's finding that the INS agents did not, by means of a show of authority, detain the workers. The Court's critical factual interpretation was that the workers were unreasonable in inferring that the INS agents stationed at all exits were there to keep them from leaving. According to the Court, the "obvious purpose of the agents' presence at the factory doors was to insure that all persons in the factories were questioned." Id. at 218.

It is difficult to imagine that a reasonable worker would have felt free to walk away when all exits were guarded. A vigorous dissent criticized the majority opinion for its "studied air of unreality" and found that the overall conditions resulted in detention. Id. at 226 (Brennan, J., concurring in part and dissenting in part). See supre text accompanying notes 4-8; see also Illinois Migrant Council v. Pilliod, 531 F. Supp. 1011, 1019 (N.D. Ill. 1982) ("when agents are stationed at points of egress, it is only reasonable to infer that they are there in order to restrict egress").

15. Because courts have used the terms "detention" and "nondetention" synonymously with "seizure" and "nonseizure," a "nondetentive seizure" would be an oxymoron under their terminology. This Note argues for severance of the linkage between seizure and detention by showing that seizures within the meaning of the Fourth Amendment can occur without restrictions on movement.

16. U.S. CONST. amend. IV.

17. The privacy interest safeguarded by the Fourth Amendment is an individual's "reasonable expectation of privacy." Brown v. Texas, 443 U.S. 47, 51 (1979).

18. See, e.g., Terry v. Ohio, 392 U.S. 1, 8-9, 20-22 (1968); Delaware v. Prouse, 440 U.S. 648, 653-54 (1979).

19. The protection of the Fourth Amendment against abusive governmental interference has been emphasized by the Court in its concern over the "'grave danger' of abuse of discretion." Prouse, 440 U.S. at 662 (quoting United States v. Martinez-Fuerte, 428 U.S. 543, 559 (1976)). The same concern is implicit in the Court's refusal to allow Fourth Amendment rights to be subject solely to the "unfettered discretion of officers in the field." Brown v. Texas, 443 U.S. 47, 51 (1979). Some commentators have observed that it would be anomalous for the Fourth Amendment to protect against arbitrary, or 
terference. In elaborating on the "inestimable right of personal security," ${ }^{20}$ the Court has emphasized that "[n]o right is held more sacred, or is more carefully guarded, by the common law, than the right of every individual to the possession and control of his own person, free from all restraint or interference of others, unless by clear and unquestionable authority of law." 21

Before Delgado, the Court had formulated a broad conception of the liberty interests embraced by the Fourth Amendment. ${ }^{22}$ For instance, in Terry v. Ohio, the Court declared that "the sounder course is to recognize that the Fourth Amendment governs all intrusions by agents of the public upon personal security."23 Although all the cases in which the Court invalidated a stop did, indeed, involve restrictions on movement, the Court recognized in those situations that intrusions on liberty were caused not only by the restrictions on movement, ${ }^{24}$ but also by the duration and nature of questioning, ${ }^{25}$ and by the creation of anxiety, fear, or concern. ${ }^{28}$ Most importantly, in explaining opposite holdings in two cases where the restrictions on movement were similar, the Court emphasized that the "psychological" or "subjective" intrusion-the arousal of anxiety, fear, or concern-was the "crucial distinction" between the two seizures. ${ }^{27}$

indiscriminate, governmental interference but not abusive, or discriminatory, official invasions. See Mertens, The Fourth Amendment and the Control of Police Discretion, 17 U. Micr. J.L. REF. 551, 552-53 (1984); Amsterdam, Perspectives on the Fourth Amendment, 58 MinN. L. REv. 349, 366 (1974).

20. Terry, 392 U.S. at 8-9.

21. Id. (quoting Union Pac. Ry. v. Botsford, 141 U.S. 250, 251 (1891) (emphasis added)).

22. The genesis of the Court's current test for a seizure was the opinion of Justice Stewart in United States v. Mendenhall, 446 U.S. 544 (1980), in a section joined by only one other Justice. Justice Stewart's explication of the new test revealed the narrowed conception of Fourth Amendment liberty his test implicitly assumed. After discussing the case law on investigative stops, Justice Stewart concluded that "[w]e adhere to the view that a person is 'seized' only when, by means of physical force or a show of authority, his freedom of movement is restrained." Id. at 553. Thus, in Justice Stewart's view, the "liberty" interest protected in Terry was equivalent to the "freedom of movement." Any restraints on liberty without a restriction on movement provided no "foundation whatever for invoking constitutional safeguards." Id.

Before Delgado, the Stewart test for a seizure already had been endorsed by six members of the Court in Florida v. Royer, 460 U.S. 491, 501-02 (1983) (plurality opinion); id. at 511-12 (Brennan, J., concurring in the result); id. at 514 (Blackmun, J., dissenting). But since a majority opinion did not emerge in Royer, it was not until Delgado that the Stewart test was applied by a clear majority of the Court.

23. 392 U.S. 1,17 n.15 (1968).

24. See, e.g., Michigan v. Summers, 452 U.S. 692, 696 (1981) (respondent not free to leave during search of his home); Prouse, 440 U.S. at 657 (stop of car interfered with freedom of movement); United States v. Brignoni-Ponce, 422 U.S. 873, 879-80 (1975) (same).

25. See, e.g., Brown v. Texas, 443 U.S. 47, 52 (1979) (stop included demand for identification); Brignoni-Ponce, 422 U.S. at $879-80$ (stop involved visual inspection and brief questioning).

26. See, e.g., Prouse, 440 U.S. at 657 (stop is inconvenient and may create substantial anxiety); Martinez-Fuerte, 428 U.S. at 558 (stop generates concern and fright); Mendenhall, 446 U.S. at 558 (stop may be threatening).

27. In one case, the Court upheld permanent checkpoint stops where all cars were slowed or stopped even though INS agents did not have reasonable suspicion that any particular automobile or occupant was involved in criminal activity. United States v. Martinez-Fuerte, 428 U.S. 543 (1976). In 
Until Delgado, the Court never had intimated that the protection against subjective intrusions was wholly dependent on a finding of a restriction on movement. By adopting this unduly narrow view of Fourth Amendment liberty interests, the Court in Delgado failed to guard adequately against subjective intrusions inflicted without a restriction on movement. Freedom from governmental interference, though, should not be any less protected merely because an intrusion is caused by nondetentive enforcement tactics. Therefore, the Gourt should focus its Fourth Amendment inquiry on whether a reasonable person would have felt an intrusion rather than limit its analysis to whether a reasonable person would have felt detained.

\section{B. Citizenship Questioning Results in a Seizure}

Citizenship questioning by the INS causes severe subjective intrusions on minority citizens and documented immigrants and should be recognized as a Fourth Amendment seizure. Minorities-the targets of most citizenship questioning by the INS ${ }^{28}$ - generally find encounters with law enforcement officers more intrusive than nonminorities because of fear of discriminatory abuse. ${ }^{29}$ Studies have indicated that police investigative practices engender resentment and hostility in minority communities, and minority groups have frequently charged that police practices are carried out in a racially discriminatory manner in order to harass. ${ }^{30}$ Recognizing

the second case, the Court invalidated stops of automobiles by the roving patrol of the INS where the agents did not have reasonable suspicion that the automobile or any occupant stopped was involved in illegal activity. United States v. Brignoni-Ponce, 422 U.S. 873 (1975). In Delaware v. Prouse, the Court explained the "crucial distinction" between Martinez-Fuerte and Brignoni-Ponce: "[The] objective intrusion-the stop itself, the questioning, and the visual inspection-also existed in rovingpatrol stops. But we view checkpoint stops in a different light because the subjective intrusion-the generating of concern or even fright on the part of lawful travelers-is appreciably less in the case of a checkpoint stop." " 440 U.S. at 656 (quoting Martinez-Fuerte, 428 U.S. at 558).

28. See infra note 56.

29. The Court has noted that "the degree of community resentment aroused by particular practices is clearly relevant to an assessment of the quality of the intrusion upon reasonable expectations of personal security caused by those practices." Terry, 392 U.S. at 17 n.14. Several senators have indicated concern about the "feeling of hysteria" expressed by members of the Hispanic community over Operation Jobs, which was a weeklong period of intensive workplace raids by the INS in April 1982. See Comment, INS Surveys of Business Establishments: Reasonable, Individualized Suspicion of Illegal Alienage, 78 Nw. U.L. REv. 632, 653 n.110 (1983).

30. See Terry, 392 U.S. at 14-15 (minorities frequently complain of wholesale harassment by the police); U.S. Comm'N ON Civil Rights, Mexican AMERICans and the ADMinistration of JusTICE IN THE SOUTHWEST 2-11 (1970) (complaints of discriminatory tactics by police include excessive use of force, verbal abuse, and frequent stops for "investigation"); Alderete, The Use of Physical Force by Police-A Perennial Chicano Community Dilemma, in National. Hispanic Conference on Law Enforcement and CRiminal Justice at 193-213 (1980); see also Davis v. Mississippi, 394 U.S. 721, 722 (1969) (overturning rape conviction of black youth, who was one of 65-75 black youths rounded up by police in dragnet investigation); Rizzo v. Goode, 423 U.S. 362, 366-67 (1976) (class action suit claiming pervasive pattern of mistreatment of minorities by police); City of Los Angeles v. Lyons, 461 U.S. 95, 116 n.3 (1983) (Marshall, J., dissenting) (disproportionate number of black victims killed by chokeholds by police). 
this greater intrusion on minorities in a Fourth Amendment context, the Supreme Court in United States $v$. Mendenhall observed that, as a black female, the respondent "may have felt unusually threatened by the officers, who were white males."31

Citizenship questioning, even without detention, far exceeds the kind of intrusions caused by ordinary police questioning; by conveying doubt about an individual's right to belong in the country, it strikes at the heart of one's claim to actual equal membership in society. Like others who have faced widespread discrimination, Hispanics-specifically targeted by the INS-cannot take for granted the right to full participation in American society. Thus, questioning by INS agents that challenges one's right to be in the country at all-much less one's claim to equal membership-is likely to be acutely disturbing and, therefore, enormously intrusive. ${ }^{\mathbf{3 2}}$

This Note will argue below that the explicit use of racial characteristics by the INS in choosing whom to question violates equal protection. ${ }^{33}$ However, even if it is decided that this use of race is not in strict violation of the equal protection clause, the norms embodied in equal protection-repugnance to disadvantaging racial classifications-should inform the analysis of the Fourth Amendment issues. Where investigation is largely directed by race, Fourth Amendment doctrine should recognize that members of minority groups will be especially resentful, because racial characteristics are the immutable traits upon which unlawful discrimination in other areas is based. Therefore, the heightened subjective intrusion experienced by minority workers should be recognized as a significant invasion on valid Fourth Amendment interests. ${ }^{34}$

31. 446 U.S. 544,558 (1980) (drug courier case). The Justices deemed the considerations "not irrelevant" but not "decisive." Id.

32. See Reeves, Reporter at Large-Boyle Heights and Beyond, New YorkER, Sept. 14, 1981, at 116,130 (Mexican American found citizenship questioning "gives you the feeling that you don't really belong here . . . . You're always ready to prove you're a citizen, that you're an American, that you belong."); Harwood, supra note 2, at 530-31 (Mexican Americans express annoyance at being mistaken for undocumented immigrant); see also Delgado, 466 U.S. at 230 (Brennan, J., concurring in part and dissenting in part) (INS agents warned worker, a citizen, that they would return to check on him because he spoke English too well).

More generally, nondetentive encounters that a reasonable person would find offensive should be regulated by the Fourth Amendment. See Terry, 392 U.S. at 15 ("courts still retain their traditional responsibility to guard against police conduct which is overbearing or harassing"); United States v. Vasquez, 612 F.2d 1338, 1343 (2d Cir. 1979) (in allowing stop of suspected drug courier, court noted that "[t]here was no evidence of harassment, intimidation, physical restraint, humiliation or prolonged questioning") (emphasis added); People v. De Bour, 40 N.Y.2d 210, 217, 352 N.E.2d 562, 567-68, 386 N.Y.S.2d 375, 380-81 (1976) ("Despite the lack of a forcible seizure[,] . . . any time an intrusion on the security and privacy of the individual is undertaken with intent to harass or is based upon mere whim, caprice or idle curiosity, the spirit of the Constitution has been violated . . . .").

33. See infra text accompanying notes 66-83.

34. See Marquez v. Kiley, 436 F. Supp. 100, 113 (S.D.N.Y. 1977) ("dominant role which physical or racial appearance inevitably plays in the officers' decision to stop and inquire . . . adds significant Fourteenth Amendment overtones"). 


\section{Constitutional Limits on Nondetentive INS Seizures}

\section{A. The Fourth Amendment Balancing Test}

Like a police force, the INS in enforcing immigration laws fulfills a law enforcement function and should be governed by the same Fourth Amendment principles that limit police activity. Courts, however, have been uniquely deferential to enforcement activities of the INS; they have not, in any rigorous, systematic fashion, used Fourth Amendment restrictions on police practices to govern INS activities. ${ }^{35}$ The nonsensical result is that a citizen or documented immigrant's Fourth Amendment rights are less jealously guarded when she is confronted and questioned by the INS seeking undocumented immigrants than when she is confronted and questioned by the police or the Federal Bureau of Investigation seeking armed robbers or murderers.

In Terry $v$. Ohio, the Supreme Court established that some police conduct that falls short of a "technical arrest" or a "full-blown search" nevertheless is governed by the Fourth Amendment. In that case, a police officer noticed two men taking turns walking back and forth numerous times along an identical route, pausing each time to stare into the same store, and then conferring together immediately after each trip. Suspecting imminent criminal activity, the officer approached the men to question and frisk them..$^{38}$

35. See generally Schuck, The Transformation of Immigration Law, 84 CoLum. L. REv. 1, 1 (1984) (immigration is area in which governmental authority is at "zenith" and individual rights at "nadir"). Congress in some instances may have greater authority with respect to individuals already determined to be noncitizens. INS enforcement activity, however, is part of the process of identifying those noncitizens, and inevitably brings the INS into contact with citizens. When noncitizens cannot be singled out, the reasons for deference do not apply.

The courts' deference also may be based on the fact that deportation is a civil proceeding and that civil sanctions are usually less severe than criminal penalties. Since INS law enforcement is said to involve ultimately less punishment, it may not need to be evaluated as strictly as criminal law enforcement. Id. at 24-27. In addition, the risk of abuse by the police may be higher than by the INS to the extent that the police potentially can impose a broader range of harsh consequences than the INS. Although the INS may subject a lawfully present individual to harassing questions, the individual ultimately can prove conclusively her legality by producing, for example, an American birth certificate. An individual stopped by the police, however, usually cannot prove his innocence of criminal charges with the same amount of certainty.

Even though deportation is considered a civil proceeding, however, punishment under the immigration laws often is as severe as a criminal penalty. Deportation may leave an individual stateless as well as cause loss of a job and separation from family members. Id. at 25-27. Even assuming that the civil penalty is less onerous, it does not follow that enforcement of civil statutes necessarily involves less intrusion than enforcement of criminal laws. See supra text accompanying notes 28-34. In addition, the risk of discriminatory abuse and short-term incarceration by the INS, in conditions that may be deplorable, is still substantial, especially for minority individuals. See, e.g., Garcia v. INS, No. 82F-680, slip op. at 23 (D. Colo. Nov. 4, 1982) (INS detention center unconstitutional because of inadequate food and bedding, unsanitary drinking and bathing facilities, and unjustified strip searches). Being required to prove lawful presence, even when it can be shown conclusively, is itself an indignity.

36. Terry, 392 U.S. at 4-7, 22-23. 
Faced with a situation in which the officer indisputably lacked probable cause to arrest the defendants for any crime until weapons were actually discovered, the Court refused either to insist on probable cause and leave the police powerless to investigate suspicious behavior or to isolate the encounter from Fourth Amendment scrutiny and leave this kind of intrusion unregulated. ${ }^{37}$ The Court instead adopted a middle ground by deciding that a seizure had occurred and by using the general Fourth Amendment requirement of reasonableness ${ }^{38}$ to evaluate "an entire rubric of police conduct . . . [that involves] necessarily swift action predicated upon the on-the-spot observations of the officer on the beat . . . "3s

To assess the reasonableness of the stop-and-frisk, the Court invoked a balancing test, weighing the governmental interests served by the seizure against the interference with Fourth Amendment liberties that the seizure entailed. ${ }^{40}$ As a result, the Court introduced the new standard of reasonable suspicion-instead of probable cause-to judge a stop-and-frisk. The Court stressed, however, that, "in justifying the particular intrusion the police officer must be able to point to specific and articulable facts which, taken together with rational inferences from those facts, reasonably warrant that intrusion" as a means to prevent or detect crime. ${ }^{41}$

Although Terry itself was expressly limited to a stop-and-frisk, ${ }^{42}$ its reasoning has since been used more generally to support what are often called Terry stops-investigative seizures by law enforcement officers that involve a brief detention. In cases involving Terry stops by the police, the Supreme Court without exception has conditioned the authority to detain an individual under the Fourth Amendment on a reasonable suspicion of criminal activity. ${ }^{43}$ Furthermore, the Court has repeatedly observed in

37. Id. at $16-20$.

38. Id. at 19-20, 24-27.

39. Id. at 20. Before Terry, probable cause was the standard against which searches and seizures were reviewed. Dunaway v. New York, 442 U.S. 200, 207-08 (1979); see also Terry, 392 U.S. at 35-39 (Douglas, J., dissenting).

40. Terry, 392 U.S. at 20-21.

41. Id. at 21. Reasonable suspicion may not be satisfied by any "inchoate and unparticularized suspicion or "hunch."' Id. at 27. The requirement of reasonable suspicion ensures that a particular seizure has a sufficient likelihood of advancing the governmental interest in question. See Mertens,
supra note 19 , at 552-53.

In addition, the scope of the intrusion must be limited. The Court in Terry, 392 U.S. at 27-30, was careful to ensure that the scope of the officer's actions was reasonably related to the circumstances that justified initiation of the encounter. In subsequent cases, the Court has continued to stress that seizures must involve limited intrusions to be considered under the balancing test. See Michigan v. Summers, 452 U.S. 692, 699 (1981) ("some seizures admittedly covered by the Fourth Amendment constitute such limited intrusions on the personal security of those detained and are justified by such substantial law enforcement interests that they may be made on less than probable cause").

42. 392 U.S. at 19 n.16.

43. See, e.g., Summers, 452 U.S. at 699 (suspicion of criminal activity required to support seizure); Delaware v. Prouse, 440 U.S. 648, 661 (1979) (same). 
those cases that reasonable suspicion was based on specific information about the particular individual questioned. ${ }^{44}$

The recent use of two police enforcement techniques-roadblocks and airport stops-suggests that in some circumstances the police may be permitted to make stops on less than individualized suspicion. For instance, in Delaware v. Prouse, the Supreme Court mentioned in dicta that the questioning of all motorists at roadblocks, since it would not involve the "unconstrained exercise of discretion," 45 may be an acceptable alternative to individualized suspicion for each motorist stopped. Lower court cases, addressing roadblock stops primarily aimed at motorists driving while intoxicated (DWI), have divided on their constitutionality. ${ }^{46}$ Those courts that have approved DWI roadblocks have relied on the important state interest in promoting traffic safety. ${ }^{47}$

Similar issues are raised when narcotics agents stop individuals at airports on the basis of a "drug courier profile."48 In the only case in which a majority of the Supreme Court explicitly addressed the constitutionality of a profile, the Court rejected its use because it was overinclusive: the profile "describe[d] a very large category of presumably innocent travelers." "49 Recently, however, a plurality of the Court allowed the use of a drug courier profile, but apparently only after finding that individualized suspicion was present: the police had discovered that the particular de-

44. See, e.g., Summers, 452 U.S. at 699 n.9 (In commenting on Ybarra v. Illinois, 444 U.S. 85 (1979), the Court observed, "we held that police executing a search warrant at a tavern could not invoke Terry to frisk a patron unless the officers had individualized suspicion that the patron might be armed or dangerous."); Brown v. Texas, 443 U.S. 47, 51 (1979) ("we have required the officers to have a reasonable suspicion, based on objective facts, that the individual is involved in criminal activity").

45. 440 U.S. 648,663 (1979).

46. Compare, e.g., Little v. State 300 Md. 485, 479 A.2d 903 (1984) and State v. Coccomo, 177 N.J. Super. 575, 427 A.2d 131, (N.J. Super. Ct. 1980) (approving DWI roadblocks) with State ex rel. Ekstrom v. Justice Ct. of Árizona, 136 Ariz. 1, 663 P.2d 992 (1983) (en banc) and Commonwealth v. McGeoghegan, 389 Mass. 137, 449 N.E.2d 349 (1983) (invalidating DWI roadblocks). See generally Note, Curbing the Drunk Driver Under the Fourth Amendment: The Constitutionality of Roadblock Seizures, 71 Geo. L.J. 1457, 1460-63 (1983).

47. See, e.g., Little, $300 \mathrm{Md}$. at 504-05, 479 A.2d at 912-13; see also Note, supra note 46, at 1460-61.

48. For example, in Florida v. Royer, 460 U.S. 491,493 n.2 (1983), the defendant: (i) carried heavy American Tourister luggage; (ii) was apparently 25-35 years old; (iii) was casually dressed; (iv) appeared pale and nervous and was looking around; (v) paid for his ticket with a large number of bills; and (vi) omitted his address and telephone number when he filled out an airline identification tag. See generally Note, Criminal Profiles After United States v. Mendenhall: How Well-Founded a Suspicion?, 1981 UTAH L. REV. 557, 561 n.31.

49. Reid v. Georgia, 448 U.S. 438, 441 (1980) (per curiam). In a case decided one month before Reid, United States v. Mendenhall, 446 U.S. 544 (1980), the Court upheld an airport stop. Three concurring Justices discussed with approval the use of the profile in the case, but maintained that "reliance upon the "drug courier profile' [would not] necessarily demonstrate reasonable suspicion." Id. at 565 n.6 (Powell, J., concurring in part and concurring in the judgment). The remaining two Justices in the majority upheld the encounter because they found it was consensual. Id. at 555-57 (opinion of Stewart, J.). 
fendant was travelling under an assumed name. ${ }^{50}$ With the discovery of the additional factor, the cumulative set of articulable facts was no longer overinclusive, because it distinguished the defendant from innocent travellers. ${ }^{.1}$

The Court also has applied the balancing test to the area of immigration law enforcement, concluding that stops for citizenship questioning are measured against the standard of reasonable suspicion..$^{82}$ In finding no detention in Delgado, however, the Court did not reach the question of whether INS stops at workplaces, like police stops, must be based on specific information about the particular individual questioned. In analyzing this question, comparison of the individual and governmental interests for both INS stops and police stops shows that the INS should be at least as constrained as the police.

\section{The Individual Interests}

In evaluating the intrusiveness of a law enforcement technique, the Court has focused on the degree of interference likely to be suffered by innocent individuals. ${ }^{53}$ Since the vast majority of undocumented immigrants sought by the INS belong to minority groups, it is reasonable to think that minorities account for a larger proportion of the innocent individuals seized by the INS compared to those seized by the police. Specifically, during workplace raids, the INS focuses questioning on Hispanic workers, including citizens and documented immigrants, because of the convergence of three factors. First, most undocumented immigrants are

50. Florida v. Royer, 460 U.S. 491, 502 (1983) (four Justices). A fifth Justice rejected the factors in the profile because "considered individually or collectively, they are perfectly consistent with innocent behavior. ..."Id. at 512 (Brennan, J., concurring in the result).

51. Similarly, lower courts, grappling with whether particular sets of facts contain individualizing "suspicious" characteristics, have identified specific factors-whether or not elements of a profile-that contribute to individualized suspicion. See, e.g., United States v. Elsoffer, 671 F.2d 1294, 1297 (11th Cir. 1982) (bulge beneath clothing); United States v. Nembhard, 676 F.2d 193, 201 (6th Cir. 1982) (defendants attempted to conceal that they were travelling together); United States v. Black, 675 F.2d 129, 137 (7th Cir. 1982) (use of alias and heightened nervousness), cert. denied, 460 U.S. 1068 (1983); see also United States v. Berry, 670 F.2d 583, 601 (5th Cir. 1982) (en banc) ("we will assign no characteristic greater or lesser weight merely because the characteristic happens to be present on, or absent from, the profile"). See generally Latzer, Royer, Profiles and the Emerging Three-Tier Approach to the Fourth Amendment, 11 AM. J. CRIM. L. 149 (1983); Note, Drug Courier Profiles in Airport Stops: Legitimate Equivalents of Reasonable Suspicion?, 14 Sw. U.L. REv. 315 (1984).

52. See United States v. Brignoni-Ponce, 422 U.S. 873, 880-82 (1975) (applying reasonable suspicion standard to stops of automobiles by INS roving patrols).

53. See, e.g., Delaware v. Prouse, 440 U.S. 648, 659-60 (1979) (invalidating random stops for license checks because of high ratio of licensed to unlicensed drivers); Brignoni-Ponce, 422 U.S. at 882 (stop of car by roving patrol for citizenship check without reasonable suspicion that particular car contained undocumented immigrants would subject motorists "to potentially unlimited interference with their use of the highways"). 
Hispanic. ${ }^{54}$ Second, the INS cannot reliably differentiate by observation among citizens, documented immigrants, and undocumented immigrants. ${ }^{\mathrm{BS}}$ Third, courts so far have permitted the INS to use race as a major factor in the selection of individuals for questioning. ${ }^{56}$ Thus, in the aggregate, because minorities find encounters with law enforcement officers more intrusive than do nonminorities, ${ }^{57}$ citizenship questioning by the INS during workplace raids interferes more severely with innocent individuals than Terry stops by the police.

\section{The Governmental Interests}

The public interest in controlling undocumented immigration is usually justified by the economic, social, and political harm caused to the United States by the presence of undocumented immigrants. ${ }^{58}$ A decade ago, the Supreme Court asserted that undocumented immigrants "create significant economic and social problems, competing with citizens and legal resi-

54. See Corwin, The Numbers Game: Estimates of Illegal Aliens in the United States, 1970 1981 , Law \& ConTemp. Probs., Spring 1982, at 223, 246, 259.

55. As Justice Brennan has stated:

Indeed, the proposition that INS agents, even those who have considerable experience in the

field, will be able fairly and accurately to distinguish between Spanish-speaking persons of

Mexican ancestry who are either native-born or naturalized citizens, and Spanish-speaking

persons of Mexican ancestry who are aliens is both implausible and subject to discriminatory abuse.

Delgado, 466 U.S. at 234 n.4 (Brennan, J., concurring in part and dissenting in part). See BrignoniPonce, 422 U.S. at 886 ("Large numbers of native-born and naturalized citizens have the physical characteristics identified with Mexican ancestry, and even in the border area a relatively small proportion of them are aliens."); United States v. Mallides, 473 F.2d 859, 860 (9th Cir. 1973) (impossible to determine by observation whether person of apparent Mexican ancestry is American citizen, Mexican national with proper entry papers, or undocumented).

56. See infra notes 73-74 and accompanying text. The INS appears to be looking primarily for undocumented Mexican immigrants during workplace raids. During Operation Jobs, $80 \%$ of those arrested were Mexican nationals. See Target: Illegal Aliens, supra note 8 , at 45 . Since the raided workplaces do not employ undocumented immigrants exclusively, many citizens and documented immigrants are affected. In the Delgado raids, at least one-half of the workforce consisted of citizens or documented immigrants. See ILGWU v. Sureck, 681 F.2d 624, 627 (9th Cir. 1982), rev'd sub nom. INS v. Delgado, 466 U.S. 210 (1984); see also International Molders' and Allied Workers' Local Union No. 164 v. Nelson, No. C-82-1896, slip op. at 31-36 (N.D. Cal. Oct. 28, 1985) (numerous citizens and documented immigrants questioned, threatened, and physically abused by INS during workplace raids). Most of those citizens and documented immigrants are likely to be Hispanic. See id. Moreover, repeated raids of the same workplaces by the INS aggravate the overall intrusiveness of the enforcement activity. For example, in Sureck the same factory was raided twice, 681 F.2d at 627 . In Blackie's House of Beef v. Castillo, 659 F.2d 1211, 1213-16 (D.C. Cir. 1981), cert. denied, 455 U.S. 940 (1982), the same restaurant was raided twice.

57. See supra text accompanying notes $28-31$.

58. Estimates of the number of undocumented immigrants in the country have ranged from one to twelve million. See, e.g., SELECT Commission ON IMMIGRATION AND REFugeE POLICY, U.S. ImMIgration Policy and the National Interest: Final Report and Recommendations 36 (1981) [hereinafter cited as SELECT Commission Final RePorT] (estimating 3.5-5.0 million); Comment, supra note 29 , at $646 \mathrm{n} .78$ (citing studies). Most recently, a study requested by the INS challenged the higher estimates and found the figure to be between 2 and 4 million. See Number of Illegal Aliens in U.S. May Be as Low as 2 Million, New Study Contends, L.A. Times, June 25, 1985, §1, at 4 , col. 1 . 
dent aliens for jobs, and generating extra demand for social services." Workplace raids are thought to be needed by the INS because of the difficulty of guarding the nation's borders. Since many undocumented immigrants enter the country to seek employment, workplace raids "strike directly at th[e] cause, enabling the INS with relatively few agents to diminish the incentive for the dangerous passage across the border and to apprehend large numbers of those who come."60 However, not even the Supreme Court seems to believe today that undocumented immigration is as big a problem as had been previously thought. The Court recently noted that undocumented immigrants "underutilize public services" and are not a burden on a state economy. ${ }^{61}$ The Court's shifting views reflect a deep division among researchers on the overall impact of undocumented immigration. ${ }^{62}$

Ultimately, even assuming that undocumented immigration imposes major social costs, the costs are certainly far lower than those caused by the crimes that Terry stops by the police are meant to control, such as the illicit sale and distribution of narcotics. ${ }^{63}$ Despite the enormous social costs of narcotics trafficking, the Court has not allowed police officers fighting narcotics to conduct Terry stops without individualized suspicion of criminal activity. ${ }^{64}$ The INS-combatting a problem of less magnitude-should be at least as circumscribed.

This initial comparison suggests that there is no reason to categorically allow the INS greater authority than the police. Citizenship questioning by the INS involves a greater personal intrusion to serve a less important governmental interest than Terry stops by the police. ${ }^{65}$

59. Brignoni-Ponce, 422 U.S. at 878-79.

60. Delgado, 466 U.S. at 223 (Powell, J., concurring in the result).

61. Plyler v. Doe, 457 U.S. 202, 228 (1982).

62. See, e.g., County of San Diego Human Resources Agency, A Study of the Socioeconomic Impact of Illegal Aliens on the County of SAN Diego 173 (1977), cited in Comment, Equal Protection for Undocumented Aliens, 5 CHICANo L. REv. 29, 36 n.40 (1981) (annual cost of undocumented immigrants to San Diego County is $\$ 2$ million in social services; gain is $\$ 48.8$ million in taxes); SElect Commission Final RePort, supra note 58, at 38-42 (undocumented immigrants do not place substantial burden on social services but they displace or depress wages of some American workers and form underclass); Salinas \& Torres, The Undocumented Mexican Alien: A Legal, Social, and Economic Analysis, 13 Hous. L. REv. 863, 876-84 (1976) (undocumented immigrants depress wages, displace American workers, drain public resources, fail to pay taxes, cause animosity toward Hispanics, and inhibit political participation of Hispanics).

63. The social costs of narcotics trafficking include: deaths from overdoses and drug-related crimes, addiction, street crime by drug users, money to support organized crime, drug abuse by adolescents, deterioration of the "moral fabric" of society; and various economic and property losses. See, e.g., Trafficking and Abuse of Narcotics in the Northeast United States: Hearing Before the House Select Committee on Narcotics Abuse and Control, 98th Cong., 1st Sess. (1983).

64. See supra text accompanying notes 48-51.

65. A more extensive comparison between workplace raids and specific police practices will be undertaken below; see infra text accompanying notes 88-102. 


\section{B. Equal Protection Under the Fifth Amendment}

Beyond the Fourth Amendment problems, INS workplace raids raise serious Fifth Amendment concerns as well. ${ }^{66}$ Under equal protection analysis, classifications that impose burdens on the basis of race are subjected to strict scrutiny. ${ }^{67}$ Such classifications bear a "very heavy burden of justification;" means must be precisely tailored to advance that purpose. ${ }^{69}$ Since the INS uses race as a means to select individuals to impose the burden of citizenship questioning, ${ }^{70}$ the racial classification employed by the INS must be subjected to strict scrutiny.

\section{Compelling Governmental Interest}

There is only one case in which the Supreme Court has approved a racial classification explicitly disadvantaging a minority after subjecting it to strict scrutiny. In Korematsu v. United States, the Court upheld the wartime exclusion of persons of Japanese ancestry from a West Coast military area. ${ }^{71}$ To justify use of such a racial classification, the Court required the government to demonstrate a "[p]ressing public necessity," which the Court found was supplied by the needs of the military during a time of war. ${ }^{22}$

In two immigration law enforcement cases, the Court has declared that the INS may impose citizenship questioning on the basis of race. In neither case, however, did the Court even mention equal protection or strict scrutiny. With respect to INS roving patrols, the Court found that "Mexican appearance [is] a relevant factor" in the selection of motorists to detain. ${ }^{73}$ With respect to stops of vehicles at permanent checkpoints, the Court found that "even if it be assumed that such referrals [to secondary

66. One exception may be the use of race when it is part of a description to identify a particular individual. The use of race as part of a particularized description rather than an "alien" or "drug courier" profile is less susceptible to abuse because only that particular individual, or someone closely resembling that person, may be stopped. It is important that there are sufficient nonracial elements in order for the description to be truly individualized. See generally Johnson, Race and the Decision to Detain a Suspect, 93 YALE L.J. 214, 242-43 (1983).

67. For a general discussion, see Developments in the Law-Equal Protection, 82 HARv. L. REv. 1065, 1087-1132 (1969). For the federal government, equal protection is included under the due process clause of the Fifth Amendment. Bolling v. Sharpe, 347 U.S. 497, 499 (1954). Administrative classifications, such as those used by the INS, are within the scope of Fifth Amendment protection. See Yick Wo v. Hopkins, 118 U.S. 356 (1886) (invalidating laundry ordinance administered discriminatorily against the Chinese).

68. Loving v. Virginia, 388 U.S. 1, 9 (1967).

69. Plyler v. Doe, 457 U.S. 202, 216-17 (1982).

70. See infra notes $73-74$ and accompanying text.

71. 323 U.S. 214 (1944).

72. Id. at $216-19$.

73. See United States v. Brignoni-Ponce, 422 U.S. $873,886-87$ (1975). 
inspection areas] are made largely on the basis of apparent Mexican ancestry, we perceive no constitutional violation." ${ }^{34}$ The Court apparently viewed race as just another factor relied on by the INS. The Court considered the use of race solely under existing Fourth Amendment doctrine and concluded that its predictive value was sufficiently high and the apprehension of undocumented immigrants sufficiently important to permit its use. But where race is employed as a "suspicious" factor for law enforcement purposes, the Fifth Amendment should come into play. The use of race should not be permitted unless the government can meet its "very heavy burden of justification."

Factory raids-or any other enforcement operations-performed by the INS do not advance a governmental interest that even approaches the magnitude of the one asserted in Korematsu. The possible protection of jobs and services-even if the loss were as great as the INS claims-does not begin to rise to the level of defending the United States against possible espionage during wartime. Before the INS should be allowed to use a racial classification, it should be required to demonstrate a pressing public necessity, a showing that it is unlikely to be able to make. ${ }^{75}$

\section{Precisely Tailored Means}

Even a pressing public necessity will not justify a burdensome racial classification if the classification is not necessary or precisely tailored to serve the governmental interest. ${ }^{78}$ The use of race by the INS satisfies neither requirement. The classification is grossly overinclusive in that there are 14.6 million Hispanics ${ }^{77}$ as compared to an estimated 3.0-4.3 million undocumented Hispanic immigrants ${ }^{78}$ in the country. Thus, be-

74. See United States v. Martinez-Fuerte, 428 U.S. 543, 563 (1976); see also Garcia v. INS, No. 82-F-680, slip op. at 7 (D. Colo. Nov. 4, 1982) (suspicion based in part on workers' Hispanic appearance and attire). The use of race by the INS affects Asian Americans as well. See, e.g., Yam Sang Kwai v. INS, 411 F.2d 683, 687 (D.C. Cir.) (INS agent, "upon entering the carryout, confronted the petitioner, . . . obviously a person of foreign descent, with questions concerning his right to be in the United States"), cert. denied, 396 U.S. 877 (1969).

75. See Johnson, supra note 66, at 249 (arguing that apprehension of undocumented immigrants does not promote pressing public necessity). Since the burden is on the government to justify its use of racial factors, uncertainty regarding the strength of the governmental purpose favors abandonment of the racial classification. See Loving v. Virginia, 388 U.S. 1, 9, 11 (1967); see also supra text accompanying notes 58-62.

76. Plyler v. Doe, 457 U.S. 202, 216-17 (1982). Accordingly, the racial classification employed by the INS should be rejected if it is unnecessary, even though it may increase the apprehension of undocumented immigrants. See McLaughlin v. Florida, 379 U.S. 184, 196 (1964) (because of existence of race-neutral statutes forbidding all promiscuous conduct, statute specifically prohibiting interracial cohabitation was unnecessary, and therefore, unconstitutional).

77. Bureau of the Census, U.S. Dep't of Commerce, State and Metropolitan Area DATA BOOK 4 (1982).

78. The figures are based on the estimate of 3.5-5.0 million undocumented immigrants reported by the President's Select Commission on Immigration and Refugee Policy, see supra note 58, and the estimate that $85 \%$ of all undocumented immigrants are Hispanic, see Corwin, supra note 54 at 
cause of the imprecision of the classification, many lawfully present Hispanics are seized for citizenship questioning because of their race. ${ }^{79}$

The racial classification is also substantially underinclusive in that about $15 \%$ of all undocumented immigrants are not Hispanic. ${ }^{80}$ By relying on race, the INS focuses disproportionately on individuals who appear to the INS to be Hispanic. For example, even though undocumented Mexican immigrants are estimated to constitute no more than $60 \%$ of the total population of undocumented immigrants in the United States, ${ }^{\mathbf{8 1}}$ they consistently account for about $90 \%$ of the undocumented immigrants apprehended by the INS, while undocumented immigrants from other countries go undetected.82 The INS's use of racial factors to target undocumented Mexicans causes Hispanic citizens and documented immigrants to be disproportionately seized for citizenship questioning, in comparison to lawfully present individuals of other racial groups. The INS's use of race is thus impermissible under equal protection analysis. ${ }^{83}$

\section{A Standard for Nondetentive Seizures}

To protect the Fourth and Fifth Amendment rights of citizens and documented immigrants working in establishments raided by the INS, the INS must not be permitted to question a worker about her citizenship without individualized reasonable suspicion of undocumented immigration (or illegal alienage). For, as this Note has argued, citizenship questioning violates the Fourth Amendment, even when the worker questioned is free to walk away. The proposed standard is the same as the one used to review detentive seizures by the police, with "undocumented immigration" substituted for "criminal activity."

248-50; Johnson, supra note 66, at 250 n.222.

79. Even though other factors may be used in combination with race, race should not be considered an additional "suspicious" factor because of this overinclusiveness.

80. See supra note 78.

81. See Corwin, supra note 54, at 246, 259; Select Commission Final RePorT, supra note 58 , at 36.

82. See Comment, supra note 29 , at $647 \mathrm{n} .82$.

83. A remaining element of equal protection analysis is the availability of alternatives that would obviate the need for a racial classification, which is an important consideration under Fourth Amendment analysis as well. The feasibility of alternatives and their constitutional significance will be discussed below. See infra text accompanying notes 95-102.

84. Three different standards have been used by the federal courts to review questioning by the INS. Three circuits have adopted a dual standard. Under the upper tier, the Fourth Amendment requires that detentive questioning be justified by individualized reasonable suspicion of illegal alienage. Under the lower tier, the INS is restricted by statute, see supra note 1, to conduct nondetentive questioning only when supported by individualized reasonable suspicion of alienage. See LaDuke v. Nelson, 762 F.2d 1318, 1331-32 (9th Cir. 1985); Illinois Migrant Council v. Pilliod, 548 F.2d 715 (7th Gir. 1977) (en banc); Au Yi Lau v. INS, 445 F.2d 217, 222-23 (D.C. Cir.), cert. denied, 404 U.S. 864 (1971).

A second standard, employed by one district court, permits detentive questioning based on individualized reasonable suspicion of alienage. See Garcia v. INS, No. 82-F-680, slip op. at 13-15 (D. Colo. 


\section{A. The Standard for Detentive Seizures by the Police}

The standard for detentive seizures by the police is individualized reasonable suspicion of criminal activity. ${ }^{85}$ The requirement of individualized information serves two functions: in requiring more specific evidence, it lowers the number of erroneous intrusions; in reducing the discretion available to law enforcement officers, it limits the possibility that the discretion will be exercised in a discriminatory manner. ${ }^{86}$

\section{B. Applying the Police Standard to INS Workplace Raids}

As argued earlier, there is insufficient reason to vest greater authority in the INS than in the police. ${ }^{87}$ The particular considerations involved in INS workplace raids support the application of the police standard to raids, and differentiate the raids from roadblocks and airport stops. ${ }^{\mathbf{8 8}}$ Those considerations are: (i) the overtly racial aspects of INS enforcement, (ii) the lesser need for immediate apprehension, (iii) the chilling effect on the employment of Hispanic citizens and documented immigrants, and (iv) the availability of alternatives.

Since the INS interacts primarily with racial minorities, the risk of abusive questioning is heightened. ${ }^{89}$ Requiring the INS to formulate individualized reasonable suspicion-which means a standard not based on

Nov. 4, 1982). Finally, the Third Circuit has permitted detentive questioning with a more open-ended Fourth Amendment requirement that the scope of an intrusion be reasonably related to its purpose, but not necessarily supported by individualized information. See Babula v. INS, 665 F.2d 293, 295-97 (3d Cir. 1981).

85. See supra text accompanying notes 43-51.

86. In Delgado, Justice Powell, the only Justice to discuss the issue of individualized suspicion, concluded that such suspicion was unnecessary for citizenship questioning during workplace raids. He analogized factory raids to the permanent checkpoint stops approved in Martinez-Fuerte-the only type of Terry stop for which the Court has expressly waived the requirement of individualized suspicion. 466 U.S. at 221-24 (Powell, J., concurring in the result). The Court's decision in MartinezFuerte, 428 U.S. 543, 561-64 (1976), turned on the finding that the stops were very limited intrusions.

Justice Powell's analogy is flawed because the factors that minimize the intrusiveness of permanent checkpoints are not present in workplace raids. In contrast to motorists who approach well-marked permanent checkpoints, workers in factories are not forewarned but are taken by surprise by the entry of the INS. Factory raids generate fear and concern among the workers and are more disruptive than checkpoint stops. See ILGWU v. Sureck, 681 F.2d 624, 640-41 (9th Cir. 1982), rev'd sub nom. INS v. Delgado, 466 U.S. 210 (1984). The location of the factories in the interior of the country, unlike the location of permanent checkpoints on main roads leading away from the border, adds to the amount of surprise. See Note, The Requirement of Individualized Suspicion: An End to INS Factory Sweeps?, 59 CHI.[-]KENT L. REv. 1069, 1092 (1984). The Court since Delgado has noted that during factory raids, "[l]arge numbers of illegal aliens are often arrested at one time, and conditions are understandably chaotic." INS v. Lopez-Mendoza, 104 S. Ct. 3479, 3487 (1984). Justice Powell's analogy also should be rejected because neither Martinez-Fuerte nor Delgado adequately recognized the substantial intrusion caused by citizenship questioning, and particularly by the racial aspects of INS enforcement activity. See supra text accompanying notes 28-34.

87. See supra text accompanying notes 35-65.

88. See supra text accompanying notes $45-51$.

89. See supra text accompanying notes 28-31. 
the overbroad and offensive racial characterizations currently used-would lower the number of citizens and documented immigrants exposed to that risk. In addition to being consistent with Fourth Amendment doctrine for other types of police conduct, this rule also would resolve the equal protection problems caused now by the INS's extensive use of race. ${ }^{80}$

Unlike the INS's use of race, stops at roadblocks are usually constrained by neutral criteria, such as the stopping of every car or of cars at fixed intervals, that minimize the selectivity, on the grounds of race or any other factor. ${ }^{91}$ Drug courier profiles, to the extent that some may include a racial component, have not been shown to rely on race to the degree that INS workplace raids do. Although recently there has been more evidence suggesting that race is a component of the profile, courts have not explicitly authorized stops in which race has been a factor. ${ }^{92}$ Moreover, the

90. By the same reasoning, courts should strike down factors used as surrogates for race, such as "foreign" appearance, a heavy accent, or inability to speak English, for they too are overbroad and descriptive of many minority citizens and documented immigrants. Other subjective factors such as apprehensiveness or furtive behavior should also be scrutinized for racial bias.

It follows, then, that citizenship questioning arising from reasonable suspicion of alienage, in place of reasonable suspicion of illegal alienage, does not satisfy constitutional guarantees because it relies heavily on "foreign" appearance. See supra note 84 for cases approving standards based on alienage. The lower standard is overinclusive not only because citizens are mistaken for aliens but also because many aliens are documented. The overinclusion affects primarily minorities since aliens-both documented and undocumented-come predominantly from Latin America and Asia. See Corwin, supra note 54, at 248-50; Note, The Factory Raid: An Unconstitutional Act?, 56 S. CAL. L. Rev. 605, 610 (1983); see also supra notes 54-56 and accompanying text.

In addition, a standard based on reasonable suspicion of alienage is essentially a standard of less than reasonable suspicion of illegality. See Delgado, 466 U.S. at 235 (Brennan, J., concurring in part and dissenting in part) ("TT]he mere fact that a person is believed to be an alien provides no immediate grounds for suspecting any illegal activity."). Such a standard would permit arbitrary law enforcement in violation of a core purpose of the Fourth Amendment. A standard of less than reasonable suspicion is likely to place most workers under suspicion, and the decision to question any particular individual would be an arbitrary one. The expanded discretion available to INS agents under a lower standard also would increase the risk that the decision to question a worker is made not on a legitimate basis but on a discriminatory basis, such as racial stereotypes or animosity. Cf. Delaware v. Prouse, 440 U.S. 648, 661 (1979) (rejecting as arbitrary automobile spot checks without reasonable suspicion of a violation).

91. See, e.g., State v. Coccomo, 177 N.J. Super. 575, 579-80, 427 A.2d 131, 133 (N.J. Super. Ct. 1980) (every fifth car checked); State ex rel. Ekstrom v. Justice Ct. of Arizona, 136 Ariz. 1, 1, 663 P.2d 992, 992 (1983) (en banc) (every car checked).

92. Some courts have mentioned the possible racial factor in drug courier profiles, but have not made any conclusive statements. For example, in United States v. Place, 660 F.2d 44, 48 (2d Cir. 1981), cert. denied, 457 U.S. 1106 (1982), the court observed that "courts [are] usually sympathetic toward upholding investigative stops" based on a number of factors, including a defendant's "appearing to be a person of Hispanic background . . . " Later in the opinion, though, the court stated that, "If]inally, an end was put to the gradual relaxation of the factors justifying reasonable suspicion by the Supreme Court in Reid v. Georgia," thus casting some doubt on whether Hispanic appearance would still be an acceptable factor. Id. at 49. See also United States v. Westerbann-Martinez, $435 \mathrm{~F}$. Supp. 690, 700 n.11 (E.D.N.Y. 1977) (noting that even if race of defendant was added to list of factors presented, reasonable suspicion not met); United States v. Vasquez, 612 F.2d 1338, 1346 (2d Cir. 1979) ("Regarding [dissenting] Judge Oakes' suggestion that Vasquez's possibly Hispanic appearance played an impermissible role in the decision to stop her, we note that the evidence . . . is ambiguous at best. When improper police conduct is identified, it must and will be condemned by this 
profiles themselves, even those that apparently do not rely on race, have received mixed responses from the courts. ${ }^{93}$

A second aspect of workplace raids is that the element of urgency is generally absent. Because employed undocumented immigrants return to the workplace every workday, the INS can take more time to investigate suspected undocumented immigrants with little risk that the workers will disappear. Furthermore, employed undocumented immigrants pose little danger of violence to society. ${ }^{94}$ Therefore, in the interest of protecting the rights of innocent workers, it is reasonable to require the INS to conduct more thorough investigations to develop individualized suspicion before conducting questioning.

By contrast, the element of urgency is a crucial part of DWI roadblocks and airport stops. With roadblocks, delay in the apprehension of drunken drivers poses an immediate risk to public safety. Similarly, a suspected drug courier who is not immediately apprehended is not likely to return to the airport the next day and give narcotics agents another chance.

A third aspect of workplace raids is that the harm to innocent individuals is significantly greater at the workplace than at roadblocks or airport stops because of the chilling effect the raids may have on employers. If the simple presence of Hispanic workers exposes employers to a greater chance of an expensive and disruptive raid, they may choose not to hire any Hispanic workers, including citizens and documented immigrants. Workplace raids, therefore, may be making it "good business" for employers to discriminate against Hispanics.

The fourth distinguishing feature of workplace raids is the feasibility of alternative enforcement techniques that serve the public interest in controlling undocumented immigration without causing the Fourth Amendment intrusions or the Fifth Amendment equal protection problems associated with racially-based dragnet operations. The constitutional difficulties aside, workplace raids do not appear even to be the most efficient way to attack undocumented immigration. Quite the contrary, evidence suggests that border enforcement is more efficient than workplace raids, as measured by the number of undocumented immigrants apprehended for each INS agent/hour. In other words, for each undocumented immigrant the INS captures at a workplace raid, it may have been able to catch several more-in the same time and with the same number of

Court.'), cert. denied, 447 U.S. 907 (1980); cf. Johnson, supra note 66, at 233-36.

93. See supra note 51.

94. Undocumented immigrants encountered by the INS are rarely armed or dangerous. Those who are suspected of other crimes usually are investigated by other law enforcement agencies, such as the Federal Bureau of Investigation or the Drug Enforcement Administration. See Harwood, supra note 2 , at 508-09. 
agents-had it instead been patrolling the borders. ${ }^{95}$ And, at the border, the INS is more likely to develop individualized suspicion from direct observation, such as evidence of recent entry. Given the greater intrusiveness of workplace raids and the greater efficacy of border patrol, the latter should be the preferred form of enforcement. ${ }^{98}$

If, despite these reasons to the contrary, the INS continues to question workers, questioning should be conducted on an individualized basis rather than through dragnet raids. In the Seventh Circuit, the INS discontinued its dragnet raids pursuant to a court order. ${ }^{97}$ The INS instead enters workplaces to look only for particular workers who are suspected of being undocumented immigrants. Chicago INS investigators have reported that the new procedures have not hindered their ability to apprehend employed undocumented immigrants. ${ }^{98}$ The experience of the INS in Chicago suggests that individualized suspicion can be formulated. The INS can work with its sources and conduct unobtrusive investigation of a workplace to refine generalized information into individualized suspicion. It is reasonable to think that the sources can provide a description or name to individualize the information. ${ }^{99}$

95. Memorandum from Peter Reich to Linda Wong and Bob Wise, INS Data on Enforcement Efficiency/INS v. Delgado, Mexican American Legal Defense and Education Fund (Aug. 2, 1983) (on file with author). Many commentators have criticized the government for allocating inadequate resources to the INS in general and to border enforcement in particular. See, e.g., Schuck, supra note 35 , at 77-78; Johnson, supra note 66 , at 249 . A revealing statistic is that the number of INS Border Patrol officers is only slightly more than twice the number of guards patrolling the U.S. Capitol, or roughly 2800 compared to 1200 . See Schuck, supra note 30 , at 77-78.

96. The government may contend that the apprehension of employed undocumented immigrants serves the additional purpose of making jobs available for lawfully present individuals. Research on the longer term effects of workplace raids suggests instead that employers re-hire the same or hire other undocumented immigrants, not citizens or documented immigrants, to fill the job openings created by raids. For example, studies and reports from various cities found that the jobs vacated because of Operation Jobs eventually were occupied again by undocumented immigrants. Citizens and documented immigrants either did not apply for those jobs or, if they did and were hired, quit within a short period. This occurred even though Operation Jobs targeted seemingly desirable, higher-paying jobs. See "Dirty Work": Americans Turn Down Many Jobs Vacated by Ouster of Aliens, Wall St. J., Dec. 6, 1982, at 1, col. 1; see also Note, supra note 32, at 611-12 (describing major INS workplace raids in which $80 \%$ of those deported returned to same jobs within three months).

97. See Comment, supra note 29 , at 669.

98. See id. The Third Circuit, rather than require individualized suspicion, has found that the questioning of all workers is a means of constraining INS discretion. See Babula v. INS, 665 F.2d 293, 296-97 (3d Cir. 1981). That approach is unsatisfactory for several reasons. First, it is often impossible for the INS to question every worker. See ILGWU v. Sureck, 681 F.2d 624, 627 (9th Cir. 1982) (INS admitting that limitation), rev'd sub nom. INS v. Delgado, 466 U.S. 210 (1984). Second, though the Third Circuit's approach eliminates selectivity as to who is questioned, questioning all workers increases the overall intrusiveness. The intrusiveness of the raids arises not only from selective questioning but also from the questions asked, see supra note 32 and accompanying text, and imposing the questioning on all workers would only aggravate the latter problem. Third, even the selectivity itself would be only marginally affected. Since the INS enters most workplaces with the owner's consent, the choice of the establishment itself is unconstrained, and is made primarily on the basis of the racial composition of the workforce. See supra note 3 and accompanying text.

99. Unobtrusive surveillance and investigation may determine the suspected individual's name, which may reveal whether the person has been deported previously. The use of an assumed name may 
Overall, therefore, the circumstances surrounding workplace raids bolster the conclusion that the authority of the INS to question workers should not exceed that of the police to conduct Terry stops. Under the Fourth Amendment, the existence of feasible alternatives indicates that the INS should pursue those possibilities rather than the more intrusive dragnet operations. ${ }^{100}$ Under the Fifth Amendment, the availability of alternatives shows that racially-based workplace raids are unconstitutional because they are not necessary to achieve the governmental interest. ${ }^{101}$ Consequently, racially-based workplace raids cannot withstand constitutional attack under either the Fourth or Fifth Amendment. ${ }^{102}$

\section{CONCLUSION}

Despite the national concern over the presence of undocumented immigrants, courts should be loath to diminish privacy and personal security, particularly when the sacrifice is made mainly by minorities. As this Note has shown, citizenship questioning by the INS interferes substantially with liberties guaranteed by the Fourth Amendment. The use of race by the INS increases the Fourth Amendment invasion and violates equal protection under the Fifth Amendment. There is no adequate justification for allowing the INS to deviate from the constitutional norms established for the police. To protect fully the rights of all citizens and documented immigrants, and especially those who are members of minority groups, the INS should be barred from questioning workers unless it has individualized reasonable suspicion based on nonracial factors that each person questioned is an undocumented immigrant.

contribute to individualized suspicion.

100. The Fourth Amendment requires the government to use the "least intrusive means reasonably available." Florida v. Royer, 460 U.S. 491,500 (1983) (plurality opinion); see id. at 511 n.* (Brennan, J., concurring in the result).

101. See note 76 and accompanying text.

102. As this Note has shown that the police standard for detentive seizures is appropriate for nondetentive INS seizures, it should be evident that a standard at least that stringent must be applied to detentive INS seizures. 